\title{
Food security and European migrant crisis: Case of Mediterranean area
}

\author{
Danilo Đokić*, Bojan Matkovski*, Žana Jurjevićc, Stanislav Zekićc
}

DOI: $10.30682 / \mathrm{nm} 2102 \mathrm{~d}$

JEL codes: F22, Q15, Q18

\begin{abstract}
This paper focuses on a possible connection between food security and the migrant crisis that began in 2015, which had a tremendous impact on the European Union as well as on the Mediterranean area. The goal of this paper is to determine if there is a correlation between the number of migrants and the levels of food security in both their homeland countries and destination countries. The PROMETHEE method was used to attempt to answer this question. Unfortunately, the analysis is limited due to lack of data for certain countries concerning food security caused by current poor political situations. Nevertheless, the results showed that the best-ranked countries by food security are mostly EU countries. These countries do not have issues with food security, especially in comparison to countries in the Middle East. Also, countries with a high level of food security and political stability have the highest influx of migrants, which suggests there is also an economic motivation for migration. Finally, the analysis confirmed a strong correlation between countries' achieved level of food security and the number of migrants.
\end{abstract}

Keywords: Food security, Migrant crisis, PROMETHEE method, Mediterranean.

\section{Introduction}

Originally, the term food security was used to describe whether a country had access to enough food to meet its population's dietary energy requirements. Food security is defined by the Food and Agriculture Organization of the United $\mathrm{Na}-$ tions (FAO) as existing when all people, at all times, have physical, social and economic access to sufficient, safe and nutritious food which meets their dietary needs and food preferences for an active and healthy life (FAO, 2019). In the most developed countries food shortages are not a problem that is in focus but food quality. According to Končar et al. (2019) the market food products of organic origin, is constantly increasing in developed countries. However, there are many reasons why food security does not exist globally. Prosekov and Ivanova (2018) suggested that the main causes of hunger and malnutrition are natural cataclysms, armed conflicts, population growth, and poverty. Reducing food insecurity for all individuals is seen as an important policy goal and can be achieved in a variety of ways: increasing world food supply, improving access to food, and increasing consumer food purchasing power (Chavas, 2017). Unfortunately, none of these solutions are viable in places where there is violent conflict. According to the State of Food Security and Nutrition in the World 2017 (FAO, IFAD, UNICEF, WFP and WHO, 2017), because many conflicts are fought in rural areas and target productive agricultural assets such as infrastructure, land, and livestock,

\footnotetext{
* Faculty of Economics, University of Novi Sad / Univerzitet u Novom Sadu, Subotica, Vojvodina, Serbia. Corresponding author: danilo.djokic@ef.uns.ac.rs
} 
the economic impacts often hit agricultural sectors disproportionately hard. Figure 1 shows that a higher level of food insecurity and undernutrition are characteristic of countries affected by conflicts. For example, in the analyzed year, the prevalence of undernourishment was $8 \%$ higher in countries affected by conflicts. It is important to note that most conflicts today are localized, so its impacts on food security are not necessarily reflected through the entire population.

In 2015, over 1 million people made their way to the EU to escape conflict in their home countries and/or to search for better economic prospects (European Commission, 2020a). Those who arrived the EU required basic humanitarian assistance, such as the provision of clean water, health care, emergency shelter, and especially food. Lack of food i.e. food security and migration are interrelated themes (Mulazzani et al., 2020). Smith and Wesselbaum (2020) have shown that low level of the food security influences migration within-country and cross-borders. Additionally, Smith and Floro (2020) concluded that severity of food insecurity increases monotonically with the likelihood of international migration intentions.

It is necessary to differentiate between the terms migrant and refugee. For example, conflict, most notably in Syria, was a major factor contributing to the significant increase in people arriving in Greece during 2015 (Crawley and Skleparis, 2018). Clearly, these peo- ple were forced to leave their homes, so they can be considered refugees and part of a refugee crisis. However, many people chose to come to the EU in search of better economic conditions rather having been forced to leave their country by an unstable political situation. These people are migrants, and a migrant crisis is primarily a socio-economic phenomenon rather than a political one. The outbreak of the recent crisis raised the question of why these people did not stay in the nearest safe country instead of undertaking the relatively risky journey to EU countries. Their decision to do so has been viewed under the false pretext of the "safe first country" as confirmation that they are migrants rather than refugees, and therefore undeserving of protection (Crawley and Skleparis, 2018). In order to explain the events that started in the Mediterranean in 2015 , the term migrant will be used in this paper. This seems most appropriate because it is difficult to determine people's true motives for leaving their homelands.

This paper will focus on issue of food security as it relates to the migrant crisis in order to determine if there is a correlation between the number of migrants and the level of food security. The PROMETHEE method was used to investigate this issue, but unfortunately, the analysis is limited mostly due to the lack of data concerning food security in certain countries with an unstable political situation.

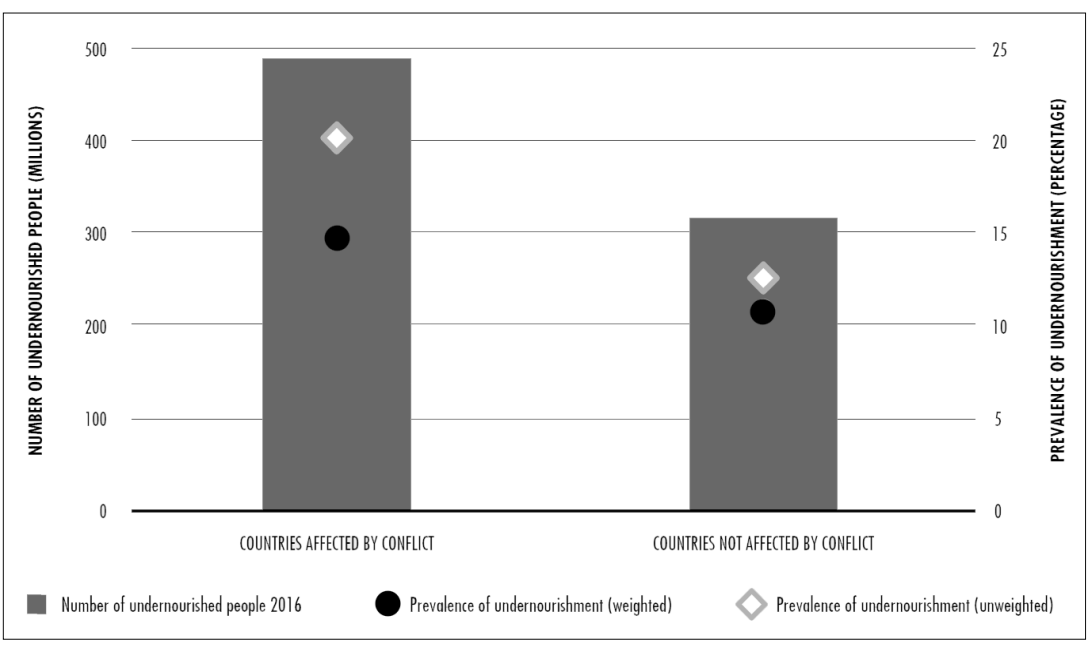

Figure 1 - Number of food-insecure people living in countries affected by conflicts and not affected by conflicts in 2016. Source: FAO, IFAD, UNICEF, WFP and WHO 2017. 
The theoretical background in this paper is divided into three sections. The first section analyses relationship between violent conflict and food security. The second section is trying to answer the question of whether and how the EU policies affect global food security. The last section analyzes the current attitude of the EUs policy towards the migrant crisis. Following this literature review, food security is analyzed in three groups of countries: selected European countries most affected by the migrant crisis (mainly Mediterranean countries) and citizenship countries of the most asylum seeker. After theoretical background, results are presented followed by discussion and conclusions.

\section{Theoretical background}

\subsection{Violent conflicts and food security}

A number of factors are adjudged to pose a threat to food security in the 21 st century, e.g. climate change, oil shortages, increased use of bio-fuels, rapidly growing demand for food in China and India, embargos and international terrorism (Hubbard and Hubbard, 2013). Recent events in the Middle East indicate that, currently, terrorism and violent conflicts are the most important menace to global food security. According to Brinkman and Hendrix (2011) war and conflict are development issues: conflict ravages local economies, often leading to forced migration, refugee populations, disease, a collapse of social trust, and acute food insecurity. For example, the civil war in the Syrian Arab Republic has caused more than 6 million people to flee their homes to other locations within the country and another 5 million to neighboring countries (FAO, IFAD, UNICEF, WFP and WHO, 2017). In most refugee situations, refugees face constraints on movement, employment and trading, which directly undermine their attempts to secure food (McGregor, 1994).

It is very difficult to determine what the causes and consequences are of this violent conflict-food security relationship. Some studies suggest that the recent increase in food insecurity can be traced to a greater number of conflicts, which are often exacerbated by climate-related shocks (FAO, IFAD, UNICEF, WFP and WHO, 2017). Dithmer and Abdulai (2017) also point out that violent conflicts and natural disasters, a high rural population share, high population growth, and inflation negatively affect food security. On the other hand, Brinkman and Hendrix (2011) suggest that food insecurity itself is a cause of conflict. For example, Maystadt et al. (2014) have identified high food prices as a possible contributing factor that added to grievances that triggered the protests of late 2010 and early 2011, first in Tunisia and then in other Near East and North African countries. If that is the case, control of the food market can be a very powerful weapon in order to achieve geopolitical goals. However, it would not be unreasonable to suggest that a strong positive correlation between food insecurity and violent conflict exists (Brück and d'Errico, 2019). Nevertheless, it should be noted that even if food insecurity is not a cause of conflict, it can still add to and exacerbate it.

\subsection{European Union policy and global food security}

Many aspects of EU policies affect global agricultural markets and food security. They include the Common Agricultural Policy (CAP), the EU bioenergy policy, trade policy, development aid policy, fisheries policy and, through different mechanisms, the EU's macroeconomic and immigration policies (Bureau and Swinnen, 2018). In this paper, only CAP and trade policy will be discussed in order to better explain these policies influence on global scale.

Launched in 1962, the EU's CAP is a partnership between agriculture and society, and between Europe and its farmers (European Commission, 2020b). One of the EU's most important policies addressing food security is the CAP. The 'guarantee of food security' concept, typical of agricultural policy after the Second World War at a time of less developed agriculture, actual food scarcity and the dependence of certain European countries on US food has been reinstated in the productivist discourse of the key document of the 2014-2020 CAP reform (Erjavec and Erjavec, 2015). As part of the 
CAP, various support systems for farmers have been implemented, which have had varying impacts on the global market. At the beginning of the 21st century, Borrell and Hubbard (2000) showed that the EU was a major source of disruption and instability for global agricultural markets due to EU agriculture exports being dumped on world markets and import demand in the EU being reduced (due to domestic production increase), which substantially lowered world prices and caused non-EU agriculture exporters to reduce production. In 2003 the CAP provides income support. A new CAP reform cuts the link between subsidies and production. Farmers now receive an income support, on condition that they look after the farmland and fulfill food safety, environmental, animal health and welfare standards (European Commission, $2020 \mathrm{~b}$ ). These reforms not only helped to reduce total agricultural support in the EU but also strongly reduced the extent of trade distortion by encouraging a shift to more-decoupled policy instruments (Anderson et al., 2013). The EU, for its part, justified continuation of agricultural support systems invoking the exceptionality of agriculture in the form of multifunctionality, and the environmental and territorial role of agriculture and small farming (Wilkinson, 2015). Another example is recent policy ideas that aim at reducing the negative externalities generated by intensive agriculture in the EU. According to Bureau and Swinnen (2018) such policies may contribute to positive environmental benefits in the EU, e.g. by reducing significantly fertilizer use, they will also reduce agricultural yields and, unless accompanied by changes in consumption, this will lead increased demand on world markets ceteris paribus. Also, the same authors stated that EU agricultural policy no longer has a considerable impact on world markets nor does it have significant negative consequences for food security. Although the CAP may no longer have such a significant negative impact on the global market, the EU is certainly responsible for previous policies that jeopardized food security in less developed countries.

Dithmer and Abdulai (2017) pointed out that the beneficial effects of openness to trade hold for dietary energy supply adequacy, as well as for dietary diversity and diet quality-related aspects of food security. The availability of food should increase with trade openness but increased trade raises concerns about import dependence for countries without a comparative advantage in food production (Brooks and Matthews, 2015). Due to World Trade Organization (WTO) negotiations, EU foreign trade protection has been decreased and tariff barriers have been drastically reduced. There are, however, still various other types of non-tariff barriers, of which the most well-known are food standards. These have existed as long as trade and exchange have, but they have been increased and expanded in recent years, which has affected global and local value chains (Swinnen, 2017). EU standards entail costs and can restrict trade, diminishing export opportunities for developing countries (Bureau and Swinnen, 2018). Czubala et al. (2009) found that robust evidence that non-harmonised standards reduce African exports of these products. EU standards which are harmonised to ISO standards are less trade restricting, but still restricting. One of the potential effects of the application of food standards is export reduction of agricultural products of less-developed countries. This can discourage local producers and pose a threat to food security in these regions.

It is very difficult to determine effects of the CAP and trade policy of EU on global food market. However, as one of the world's leading economies, the EU has considerable global influence on political, social, and economic developments. With such power, the EU can take an adequate reaction in the crisis conditions, like recent migrant crisis.

\subsection{EU and migrant crisis}

According to McGregor (1994) the food security of areas where there are involuntary migrants is context specific and its understanding requires an analysis of the local economy and ecology, the relationships between migrants and their hosts, the nature of the assistance programmes and the structure of broader political relations and conflicts. This paper will only analyse the relationship between migrants and their hosts - in this case the EU. The situation is more 
complicated because the EU consists of different economically developed countries that each took a various position regarding the migrant crisis. Even though the EU is always in the process of crafting a common position, the EU clearly met this crisis with disunity and without a common stance. As Grigonis (2016) states, the absence of a comprehensive migrant policy at the EU level led it to facing the crisis divided and indecisive despite historical experience suggesting the crisis could have been anticipated, and many of the human rights violations occurring in it its wake could have been avoided. Some countries opened their doors to all asylum-seekers, whereas a limited number of countries (notably, Poland, Hungary, and the Czech Republic) refused to accept migrants at all, thereby challenging the legitimacy of the EU's legal decision (Braghiroli and Makarychev, 2018). According to Klímová and Rosková (2017), from an economic perspective, the Czech Republic would be able to integrate the number of immigrants required by EU quotas. But they also warn that since it is not possible to determine the exact number of migrants, quotas could increase, in which case the economic stability of the Czech Republic will be critical.

The EU, together with its Member States, is a leading donor of humanitarian aid in all the major countries and regions, from where migrants currently arriving to the EU originate. This includes Syria, Iraq, Afghanistan, Pakistan, the Horn of Africa and the Sahel. In 2015, the European Commission provided over $72 \%$ of its annual humanitarian aid budget (over $€ 1$ billion) to projects helping refugees and internally displaced persons (European Commission, 2020a). The effectiveness of such aid is questionable because the situation is aggravated by refugee and economic migrant's relation. As already noted, there are indications that there are many economic migrants in these movements of people and the question is whether assistance should be directed towards them or towards those who have fled from the regions affected by violent conflicts. Crawley et al. (2016) concluded that this crisis was not the result of a natural or unforeseen disaster; rather it was in large part a policy driven crisis sustained by the failure of the EU to put in place adequate and humane pol- icies to deal with this unprecedented but in fact foreseeable movement of people. Although this is probably not the EU failure, but the adequate and unique strategy could alleviate the consequences of the crisis. Europe is still divided over this issue, and one could argue that the migrant crisis has shaken the basic foundations of European values. According to Brekke and Brochmann (2015) there is a discrepancy between the reality and the ambitions of the EU to create a harmonized system for asylum seekers because national differences toward migration crisis undermine the supranational efforts to coordinate policies across the region.

\section{Materials and methods}

This study focuses on three groups of countries (Figure 2). The first group includes the countries in which asylum seekers hold citizenship (negative numbers in Figure 2), and the second includes countries with the highest number of asylum applicants (destination countries). Of these destination countries, more than a third of all migrants applied for asylum in Germany $(36.86 \%)$. Also, only countries with a share greater than 3\% were included in the analysis. The third group consists of what are considered transit countries: Turkey, North Macedonia, Romania, Bulgaria, Slovenia, Croatia, Bosnia and Herzegovina and Serbia. Some authors (Samek Lodovici et al., 2017; Stevens, 2018) involve Italy, Greece, and Hungary in a transit country group. There is no consensus in the literature and a formal definition that could answer whether these countries are transit or destination countries. In fact, they could be considered both. However, as they have a large influx of migrants based on the data shown in Figure 2, they will be classified as destination countries in this paper.

In order to rank countries by food security performances, the PROMETHEE method (the Preference Ranking Organization Method for Enrichment Evaluations) as defined by Mareschal, Brans and Vincke (1984) was used. PROMETHEE I (partial ranking) and PROMETHEE II (complete ranking) were developed by J.P. Brans and were first presented in 1982 at a conference at the Université Laval, Québec, Canada 
Figure 2 - First-time asylum seekers in EU Member States by country of citizenship and number of first-time applicants, 2015-2019.

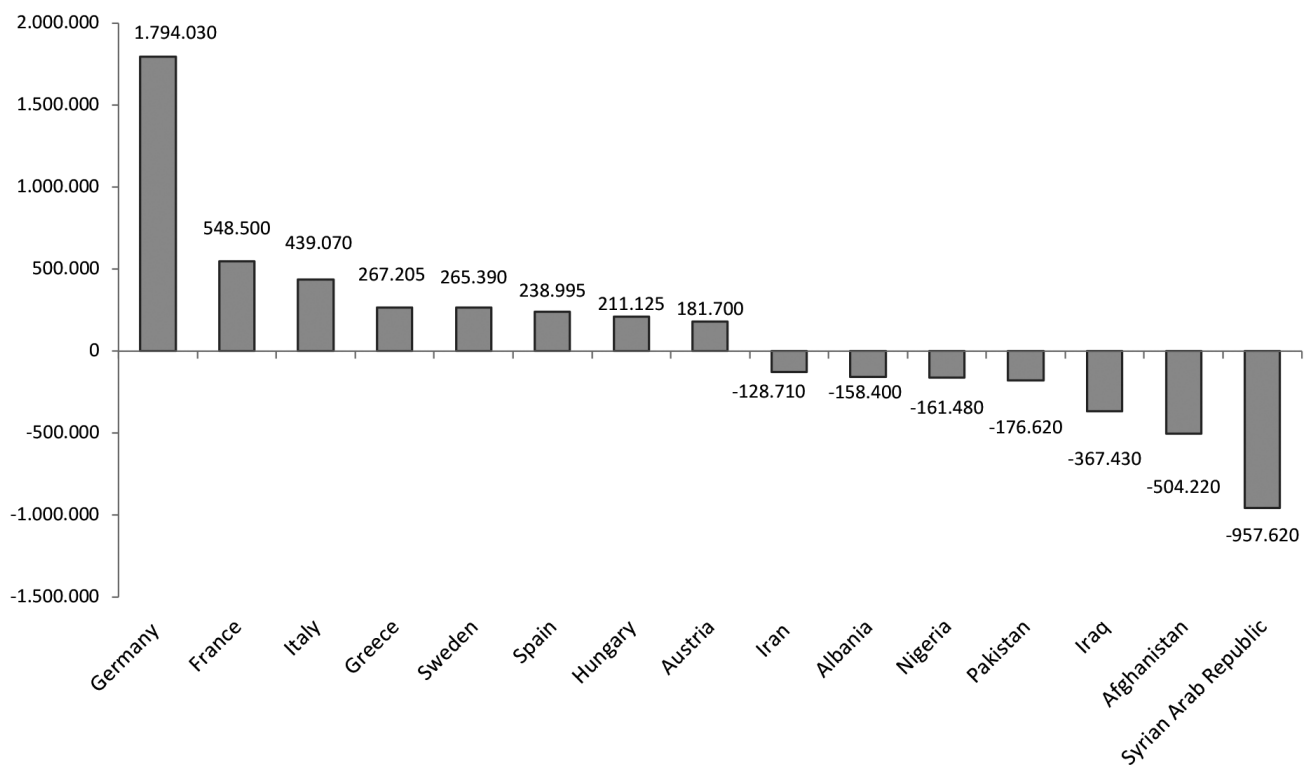

Source: Eurostat, 2020.

(Brans and Mareschal, 2005). This method resolves issues with multi-criteria ranking based on a number of criteria that are often presented as different units. When using this method, the data often varies significantly. Criteria (maximum or minimum) are defined according to the user's preferences. For example, in the case of food security, political stability would be considered a maximum criterion and gives a higher ranking to a country with a more stable political situation. For more detail about the PROMETHEE methodology, see the PROMETHEE 1.4 Manual (2013).

This method has not often been applied in the field of agricultural economics. However, there are several recent studies in which this method was used. For example, Talukder and Hipel (2018) applied this method to five different types of agricultural systems in coastal Bangladesh in order to rank alternatives from most to least suitable according to a range of sustainability indicators. Zekić et al. (2018) used this method to rank EU countries according to the impact of agriculture on the environment. When studying the economic performances of agriculture, Birovljev et al. (2017) also used this method to rank former CEFTA countries.

For our study, visual PROMETHEE software was used to rank countries according to their level of food security. As was previously mentioned, lack of data was the main limitation in this study. Even within the Global Food Security Index (GFSI, 2020), results for a few countries are missing from the sample. Unfortunately, there are only a few FAO indicators of food security for which data existed for all countries. Some indicators have been excluded due to the difficulty in defining criteria in the PROMETHEE analysis. For example, there is data for obesity, which is becoming increasingly prevalent in nearly every country, including developing countries $(\mathrm{Ng}$ et al., 2014). However, the focus of this paper is the issue of food scarcity, so it would not be appropriate here to determine a criterion to minimize obesity. Therefore, the analysis includes 4 indicators within the scope of different dimensions of food security: average dietary energy supply adequacy, average value of food production, gross domes- 
tic product per capita, and political stability and the absence of violence/terrorism. All the data was retrieved from the FAOSTAT (2020) and the World Bank (2020).

\section{Results and discussion}

Our analysis includes indicators that are within the scope of different dimensions of food security, and significant differences in the data (five years average 2015-2019) among these three groups of countries is noticeable. As would be expected, the destination countries had the best results for all variables, followed by those for transit countries, and citizenship countries had the worst results (Table 1).

Table 2 shows the results from ranking these countries according to food security. The bestranked country is Austria, followed by the most developed countries in the EU (France, and Germany). It is worth noting that the group of countries with positive results are mostly EU countries, with the addition of Albania and Turkey. As expected, these countries do not have food security problems, especially in comparison to countries of the Middle East and South Asia. According to Chabot and Dorosh (2007), roughly half of Afghanistan's rural population lives in poverty and one-third of the rural population does not consume an adequate amount of calories. In rural areas of Pakistan, 80 out of 120 districts are food insecure (of which 38 are extremely food insecure) and there is a need for increased food production (Ejaz et al., 2012). In few countries of the world food security has been so much affected by political developments as in Iraq, the rise (and fall) of the Islamic State in Iraq and Syria (ISIS) is only the latest event in a string of political impacts on food security (Woertz, 2017). Lampietti et al. (2011) suggest three strategies for Arab countries that could reduce vulnerability to price shocks (and improve food security): strengthening safety nets, enhancing domestic food production (by increasing investment in research and development

Table 1 - Descriptive statistics for the sample.

\begin{tabular}{|c|c|c|c|c|c|}
\hline & & $\begin{array}{c}\text { Average } \\
\text { dietary } \\
\text { energy supply } \\
\text { adequacy } \\
\text { (percent) }\end{array}$ & $\begin{array}{l}\text { Average } \\
\text { value of food } \\
\text { production } \\
\text { (constant 2004- } \\
2006 \text { I\$/cap) }\end{array}$ & $\begin{array}{c}\text { Gross domestic } \\
\text { product per capita, } \\
\text { PPP, dissemination } \\
\text { (constant 2011 } \\
\text { international \$) }\end{array}$ & $\begin{array}{c}\text { Political } \\
\text { stability and } \\
\text { absence of } \\
\text { violencel } \\
\text { terrorism (index) }\end{array}$ \\
\hline \multirow{3}{*}{ Average } & Citizenship countries & 116.75 & 229.57 & $7,395.57$ & -1.84 \\
\hline & Transit countries & 126.88 & 388.25 & $23,112.38$ & -0.03 \\
\hline & Destination countries & 134.88 & 507.75 & $43,100.13$ & 0.50 \\
\hline \multirow{3}{*}{ StDev } & Citizenship countries & 13.13 & 138.62 & $5,062.56$ & 1.14 \\
\hline & Transit countries & 12.86 & 81.43 & $7,632.11$ & 0.79 \\
\hline & Destination countries & 6.94 & 121.68 & $10,037.12$ & 0.40 \\
\hline \multirow{3}{*}{$\mathrm{CV}$} & Citizenship countries & $11 \%$ & $60 \%$ & $68 \%$ & $-62 \%$ \\
\hline & Transit countries & $10 \%$ & $21 \%$ & $33 \%$ & $-3000 \%$ \\
\hline & Destination countries & $5 \%$ & $24 \%$ & $23 \%$ & $79 \%$ \\
\hline \multirow{3}{*}{ Max } & Citizenship countries & 134.75 & 467 & 13,813 & 0.36 \\
\hline & Transit countries & 149.5 & 483 & 36,459 & 0.93 \\
\hline & Destination countries & 145 & 653 & 54,705 & 1 \\
\hline \multirow{3}{*}{ Min } & Citizenship countries & 95 & 54 & 2,032 & -2.81 \\
\hline & Transit countries & 112 & 259 & 13,852 & -1.65 \\
\hline & Destination countries & 125.75 & 290 & 29,250 & -0.08 \\
\hline
\end{tabular}

Source: Authors' calculations based on FAOSTAT and World Bank data. 
Table 2 - Results of the PROMETHEE method ranking.

\begin{tabular}{|ccc|ccc|}
\hline Rank & Country & Phi & Rank & Country & Phi \\
\hline 1 & Austria & 0.8409 & 13 & Croatia & 0.0455 \\
2 & France & 0.5682 & 14 & Bulgaria & -0.1136 \\
3 & Germany & 0.5227 & 15 & Serbia & -0.2273 \\
4 & Spain & 0.5114 & 16 & Iran & -0.2727 \\
5 & Italy & 0.4773 & 17 & North Macedonia & -0.2727 \\
6 & Hungary & 0.4318 & 18 & Bosnia & -0.2841 \\
7 & Romania & 0.3636 & 19 & Nigeria & -0.6591 \\
8 & Greece & 0.3409 & 20 & Syrian Arab Republic & -0.7273 \\
9 & Turkey & 0.3182 & 21 & Iraq & -0.7727 \\
10 & Sweden & 0.2727 & 22 & Pakistan & -0.8409 \\
11 & Slovenia & 0.2273 & 23 & Afghanistan & -0.9318 \\
12 & Albania & 0.1818 & & & \\
\hline
\end{tabular}

Source: Authors' calculations based on FAOSTAT and World Bank data.

to increase productivity), and reducing exposure to market volatility. Such strategies can be useful, but only under peaceful conditions. In situations where there are major conflicts, such strategies are essentially useless.

The difficulties of EU policies to respond effectively to the increased movement of people across the Mediterranean that started in 2015 was partly a reflection of political differences and tensions within and among EU Member States, but it also reflected flawed assumptions about the reasons for why people move and the factors shaping their longer-term migration trajectories and their journeys to Europe (Crawley et al., 2016). We also analysed the eastern migration route, and Figure 3 shows the classification

Figure 3 - Eastern route of migration and food security.

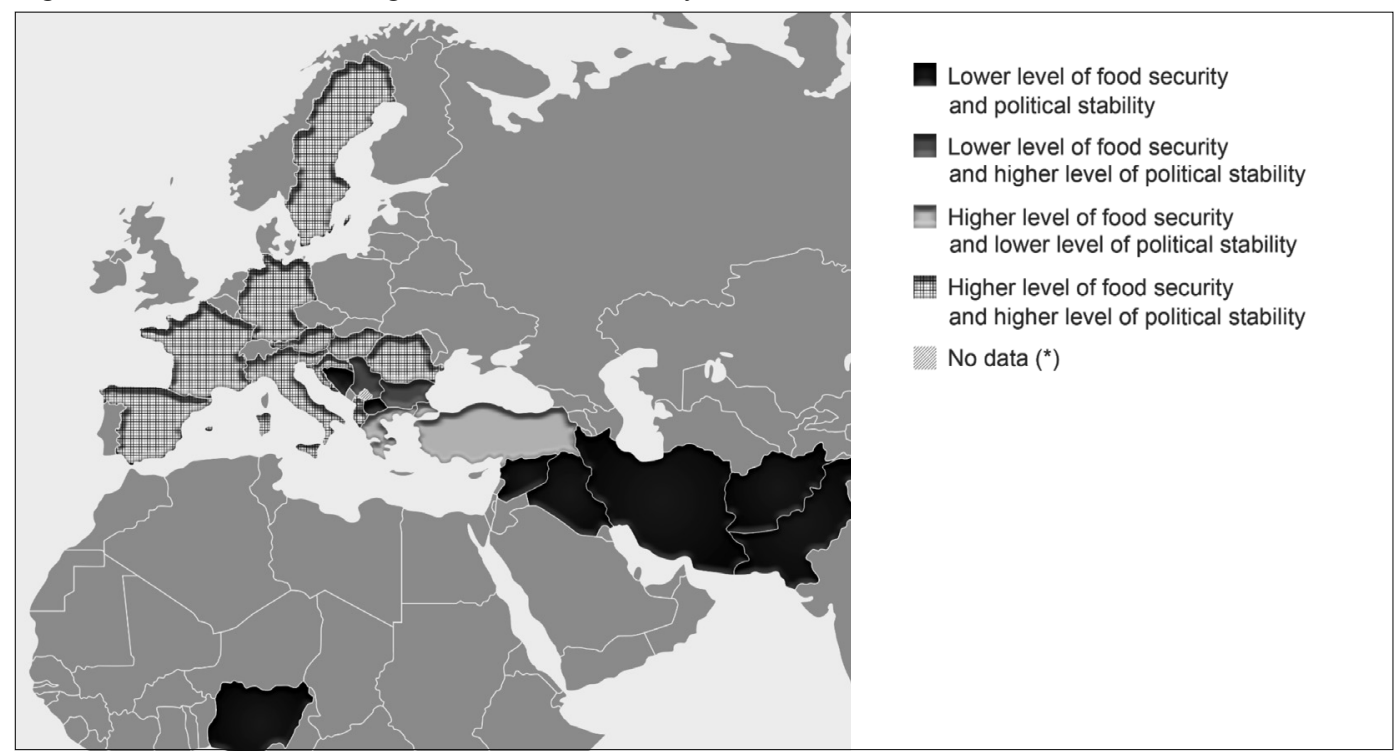

Source: Authors' illustration based on FAOSTAT and World Bank data. 
Figure 4 - The number of migrants and the food security index.

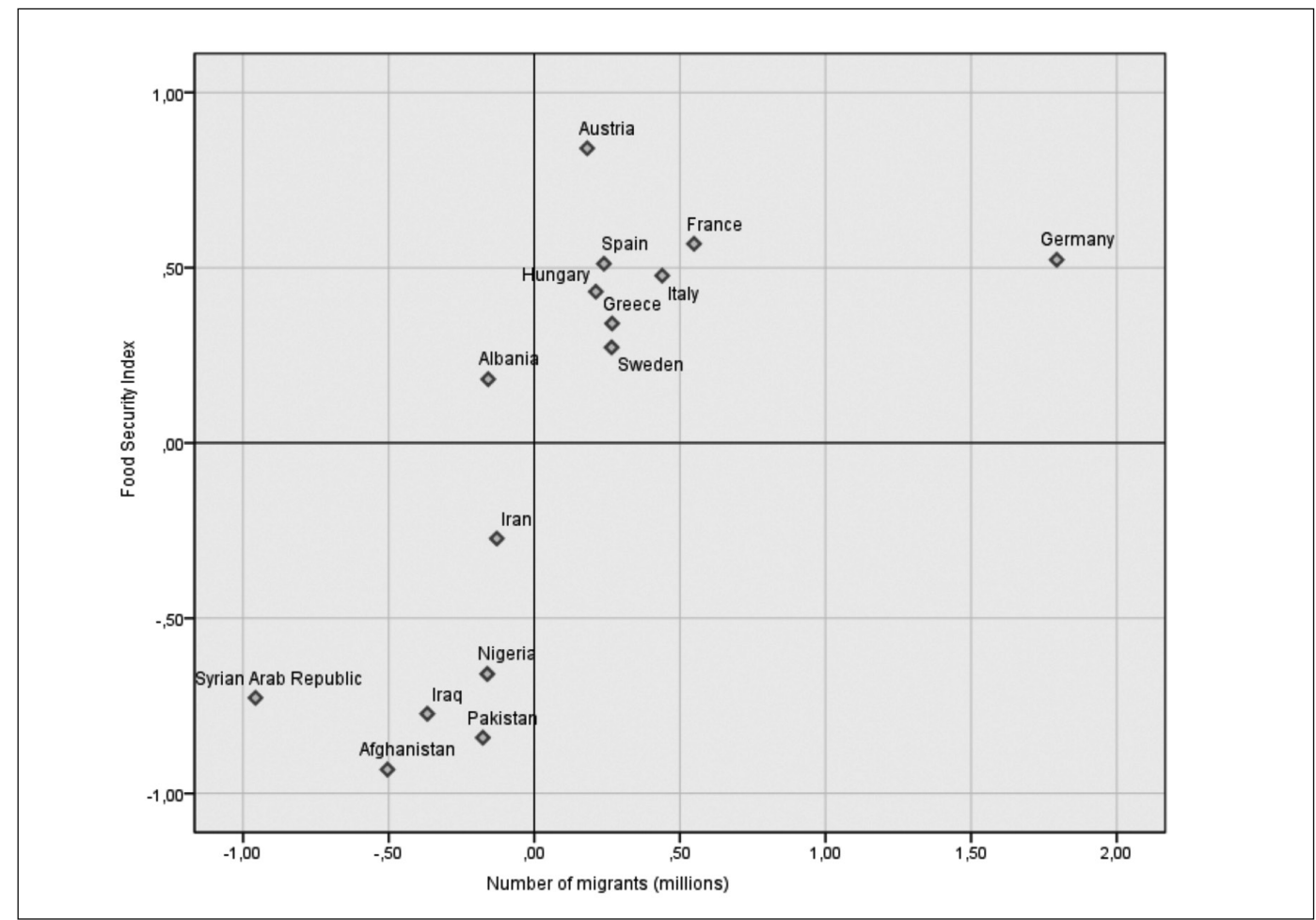

Source: Authors'illustration based on FAOSTAT and World Bank data.

of countries along this route according to levels of food security and political stability (there is no data for Kosovo under UNSCR 1244/99).

Citizenship countries with the most asylum seekers have low levels of food security and political stability, and these certainly may also be motivations behind people's decision to leave their country. It is particularly interesting that countries with high levels of food security and political stability have the highest influx of migrants, which would seem to indicate there is an economic motivation driving migration. One case that seems to clearly illustrate economic motivation is that of Albania. It has a satisfactory level of food security and political stability but also has a large number of emigrants, which is a strong indication the reason for migration is economic.

Figure 4 additionally explains the previous statements. It shows the relationship between the number of migrants and the food security index, where is noticeable that almost all citizen- ship countries have a low level of food security (Quadrant III). Among them, only Albania has a positive food security index (Quadrant II). All destination countries have a positive food security index (Quadrant I). As expected, there is no destination country with a negative food security index (Quadrant IV).

Nevertheless, according to our analysis, the correlation coefficient between the level of food security achieved (obtained by ranking with the PROMETHEE method) and the number of emigrants and immigrants is 0.70 . Such results are in line with the conclusions of Brinkman and Hendrix (2011), who found that food insecurity heightens the risk of democratic breakdown, civil conflict, protest, rioting, and communal conflict. The migrant crisis is thus a logical consequence of such unfavorable social events.

The issue of food security, especially when connected to major upheavals like the migrant crisis, requires a global response. In resolving this challenge, the EU can make a significant 
contribution. It is necessary to involve both governmental and non-governmental institutions as well as the private and civil sectors. Two key factors for improving food security are economic development and political stability. Simply increasing the income of the population in order to solve the problem of food security is not sufficient. An increase in per capita Gross Domestic Products indicates income growth, but it does not reflect income distribution across the population or people's level of wellbeing (Sen, 1985). As was previously mentioned, the CAP and EU trade policy can slow down the economic development of less developed countries, and especially that of the food sector. The EU should create a more responsible policy in line with its influence that will not have a negative impact on global trends, or would at least reduce its impact. Unfortunately, too many factors are involved in determining political stability, and it is beyond the scope of this paper to offer solutions to the problem. Conflict is a key factor in explaining the apparent reversal in the long-term declining trend in global hunger, and thus poses a major challenge to ending hunger and malnutrition (FAO, IFAD, UNICEF, WFP and WHO, 2017). However, due to orientation on ex post rights defence, the EU's system was also practically unsuitable to defend the rights of the asylum seekers after human rights violations had already occurred (Grigonis, 2016). As Fanzo (2015) states, without strong values and ethical standards that set nutrition as a high priority for the improved development of citizens and their countries, progress in achieving global food security will remain stagnant.

\section{Conclusion}

Since there are a limited number of studies analyzing food security and the migrant crisis, this paper contributes to filling this gap in literature. Despite the limitations of our study, our conclusions can be summarized as follows:

The migrant crisis, primarily caused by political instability followed by violent conflicts, can also be associated with food insecurity as a factor that encourages and directs migration. Even if food insecurity is not a key cause of that conflict, we believe that this problem needs multidimensional approach.

Results showed that countries in the study with the highest food security levels are primarily EU countries. Countries with a high level of food security and political stability have the highest influx of migrants.

There is a strong correlation $(\mathrm{r}=0.70)$ between the level of food security achieved and the number of migrants.

The EU must create a more responsible policy in line with its influence that will not have a negative impact on global trends or would at least reduce it. The issues of food insecurity and violent conflict must be resolved simultaneously. A unified policy towards a migrant crisis is not a sufficient solution. A comprehensive analysis of the factors that have contributed to the emergence of this problem and corrections in EU policies is necessary to reduce the risk of such crises reoccurring.

If a more comprehensive index of food security were created, it could serve as an early warning of an impending migrant crisis. The EU could then provide more effective aid to vulnerable populations and prevent the problems that arose during this migrant crisis. To create this index, quality data must be made available.

Expanding the analysis over a longer period of time as well as including additional variables should be the subject of future studies.

\section{References}

Anderson K., Rausser G., Swinnen J., 2013. Political economy of public policies: insights from distortions to agricultural and food markets. Journal of Economic Literature, 51(2): 423-477. DOI: 10.1257/jel.51.2.423.

Birovljev J., Đokić D., Matkovski B., Kleut Ž., 2017. Economic performances of agriculture of CEFTA and former CEFTA countries. Economics of Agriculture, 64(4): 1413-1424. UDC: 338.431(4-191.2).

Borrell B., Hubbard L., 2000. Global economic effects of the EU Common Agricultural Policy. Economic Affairs, 20(2): 18-26. DOI: 10.1111/14680270.00218 .

Braghiroli S., Makarychev A., 2018. Redefining Europe: Russia and the 2015 refugee crisis. Geopolitics, 23(4): 823-848. DOI: 10.1080/14650045.2017.1389721. 
Brans J.P., Mareschal B., 2005. PROMETHEE methods. In: Multiple criteria decision analysis: state of the art surveys. New York, NY: Springer, pp. 163186. DOI: 10.1007/0-387-23081-5_5.

Brekke J.P., Brochmann G., 2015. Stuck in transit: secondary migration of asylum seekers in Europe, national differences, and the Dublin regulation. Journal of Refugee Studies, 28(2): 145-162.

Brinkman H.J., Hendrix C.S., 2011. Food Insecurity and Violent Conflict: Causes. Consequences, and Addressing the Challenges. Occasional paper. Rome: World Food Programme.

Brooks J., Matthews A., 2015. Trade dimensions of food security. OECD Food, agriculture and Fisheries Papers, 77. Paris: OECD Publishing. https://doi. org/10.1787/5js65xn790nv-en.

Brück T., d'Errico M., 2019. Food security and violent conflict: Introduction to the special issue. World Development, 117: 167-171. DOI: 10.1016/j. worlddev.2019.01.007.

Bureau J.C., Swinnen J., 2018. EU policies and global food security. Global food security, 16: 106-115. DOI: 10.1016/j.gfs.2017.12.001.

Chabot P., Dorosh P.A., 2007. Wheat markets, food aid and food security in Afghanistan. Food Policy, 32(3): 334-353.

Chavas J.P., 2017. On food security and the economic valuation of food. Food policy, 69: 58-67. DOI: 10.1016/j.foodpol.2017.03.008.

Crawley H., Düvell F., Jones K., McMahon S., Sigona N., 2016. Destination Europe? Understanding the dynamics and drivers of Mediterranean migration in 2015. MEDMIG Final Report. Available online: http://www.medmig.info/ research-brief-destination-europe/ (Last accessed 27 August 2020).

Crawley H., Skleparis D., 2018. Refugees, migrants, neither, both: categorical fetishism and the politics of bounding in Europe's 'migration crisis'. Journal of Ethnic and Migration Studies, 44(1): 48-64. DOI: 10.1080/1369183X.2017.1348224.

Czubala W., Shepherd B., Wilson J.S., 2009. Help or hindrance? The impact of harmonised standards on African exports. Journal of African Economies, 18(5): 711-744.

Dithmer J., Abdulai A., 2017. Does trade openness contribute to food security? A dynamic panel analysis. Food policy, 69: 218-230. DOI: 10.1016/j. foodpol.2017.04.008.

Ejaz Ali Khan R., Azid T., Usama Toseef M., 2012. Determinants of food security in rural areas of Pakistan. International Journal of Social Economics, 39(12): 951-964. DOI: 10.1108/03068291211269082.
Erjavec K., Erjavec E., 2015. 'Greening the CAP'Just a fashionable justification? A discourse analysis of the 2014-2020 CAP reform documents. Food Policy, 51: 53-62. DOI: 10.1016/j.foodpol.2014.12.006.

European Commission, 2020a. Forced displacement: refugees, asylum-seekers and internally displaced people (IDPs). Bruxelles, European Civil Protection and $\mathrm{Hu}-$ manitarian Aid Operations. Available online: https:// ec.europa.eu/echo/refugee-crisis (Last accessed 11 April 2019).

European Commission, 2020b. The common agricultural policy at a glance. Available online: https:// ec.europa.eu/info/food-farming-fisheries/key-policies/common-agricultural-policy/cap glance_en (Last accessed 15 April 2019).

EUROSTAT, 2016. Asylum in the EU Member States: Record number of over 1.2 million first time asylum seekers registered in 2015. Eurostat Newsrelease, 44/2016.

EUROSTAT, 2020. Database. Available online: https:// ec.europa.eu/eurostat/web/asylum-and-managed-migration/data/database (Last accessed 20 September 2020).

Fanzo J., 2015. Ethical issues for human nutrition in the context of global food security and sustainable development. Global Food Security, 7: 15-23. DOI: 10.1016/j.gfs.2015.11.001.

FAO, 2019. Food Security Statistics. Rome: Food and Agriculture Organisation, United Nations. http:// www.fao.org/economic/ess/ess-fs/en/ (Last accessed 30 March 2019).

FAO, IFAD, UNICEF, WFP, WHO, 2017. The State of Food Security and Nutrition in the World 2017. Building resilience for peace and food security. Rome: Food and Agriculture Organisation, United Nations.

FAOSTAT, 2020. Database. Available online: http:// www.fao.org/faostat/en/\#home (Last accessed 20 September 2020).

GFSI (Global Food Security Index), 2020. Database. Available online: https://foodsecurityindex.eiu. com/ (Last accessed 15 September 2020).

Grigonis S., 2016. EU in the face of migrant crisis: Reasons for ineffective human rights protection. International Comparative Jurisprudence, 2(2): 93-98. DOI: 10.1016/j.icj.2017.01.003.

Hubbard L.J., Hubbard C., 2013. Food security in the United Kingdom: External supply risks. Food Policy, 43: 142-147.

Klímová M., Rosková L., 2017. The economic consequences of the contemporary European migration crisis on the Czech Republic. Kontakt, 19(4): 253262. DOI: 10.1016/j.kontakt.2017.09.011. 
Končar J., Grubor A., Marić R., 2019. Improving the placement of food products of organic origin on the AP Vojvodina market. Strategic Management, 24(3): 24-32. DOI: 10.5937/StraMan1903024K.

Lampietti J.A., Michaels S., Magnan N., McCalla A.F., Saade M., Khouri N., 2011. A strategic framework for improving food security in Arab countries. Food Security, 3(1): 7-22. DOI: 10.1007/s12571010-0102-3.

Mareschal B., Brans J.P., Vincke P., 1984. PROMETHEE: A new family of outranking methods in multicriteria analysis. ULB Institutional Repository 2013/9305. ULB--Université Libre de Bruxelles.

Maystadt J.F., Tan J.F.T., Breisinger C., 2014. Does food security matter for transition in Arab countries? Food Policy, 46: 106-115. DOI: 10.1016/j. foodpol.2014.01.005.

McGregor J., 1994. Climate change and involuntary migration: implications for food security. Food Policy, 19(2): 120-132. DOI: 10.1016/03069192(94)90065-5.

Mulazzani L., Manrique R., Stancu C., Malorgio G., 2020. Food security and migration in Africa: a validation of theoretical links using case studies from literature. New Medit, 19(2): 19-36. DOI: 10.30682/ nm2002b.

Ng M., Fleming T., Robinson M., Thomson B., Graetz N., Margono C., ... Abraham J.P., 2014. Global, regional, and national prevalence of overweight and obesity in children and adults during 1980-2013: a systematic analysis for the Global Burden of Disease Study 2013. Lancet, 384(9945): 766-781. DOI: 10.1016/S0140-6736(14)60460-8.

PROMETHEE 1.4 Manual, 2013. Available online: http://www.promethee-gaia.net/visual-promethee. html (Last accessed 27 March 2019).

Prosekov A.Y., Ivanova S.A., 2018. Food security: The challenge of the present. Geoforum, 91: 73-77. DOI: 10.1016/j.geoforum.2018.02.030.

Samek Lodovici M., Drufuca S.M., Orlando N., Crepaldi C., Pesce F., Koulocheris S., Borbély S.,
2017. Integration of refugees in Greece, Hungary and Italy: Comparative analysis. Directorate-General for Internal Policies, Policy Department A: Economic and Scientific Policy. Bruxelles: European Union.

Sen A., 1985. Well-being, agency and freedom: The Dewey lectures 1984. The Journal of Philosophy, 82(4): 169-221. DOI: 10.2307/2026184.

Smith M.D., Floro M.S., 2020. Food insecurity, gender, and international migration in low-and middle-income countries. Food Policy, 91, 101837. https://doi.org/10.1016/j.foodpol.2020.101837.

Smith M.D., Wesselbaum D., 2020. COVID-19, Food Insecurity, and Migration. The Journal of nutrition, 150(11): 2855-2858.

Stevens D., 2018. Greece as a 'transit country': The role of law and policy. Journal of Ethnic and Migration Studies, Special Issue 'Transit countries: challenges, pressures and compromises', Missbach A., Phillips M. (eds.).

Swinnen J., 2017. Some dynamic aspects of food standards. American Journal of Agricultural Economics, 99(2): 321-338. DOI: 10.1093/ajae/aax022.

Talukder B., Hipel K.W., 2018. The PROMETHEE Framework for Comparing the Sustainability of Agricultural Systems. Resources, 7(4): 74. DOI:10.3390/resources7040074.

Wilkinson J., 2015. Food security and the global agrifood system: Ethical issues in historical and sociological perspective. Global food security, 7: 9-14. DOI: 10.1016/j.gfs.2015.12.001.

Woertz E., 2017. Food security in Iraq: results from quantitative and qualitative surveys. Food Security, 9(3): 511-522. DOI: 10.1007/s12571-017-0666-2.

World Bank, 2020. Database. Available online: https://data.worldbank.org (Last accessed $20 \mathrm{Au}-$ gust 2019).

Zekić S., Kleut Ž., Matkovski B., Đokić D., 2018. Determining agricultural impact on environment: Evidence for EU-28 and Serbia. Outlook on Agriculture, 47(2): 116-124. DOI: 10.1177/0030727018768016. 